\title{
Comparative in vitro antioxidant potential of different parts of Ipomoea asarifolia, Roemer \& Schultes, Guiera senegalensis, J. F. Gmel and Anisopus mannii N. E. Brown
}

\author{
Sunday Ene-OjoAtawodi*, Gboyega Suleiman Onaolapo \\ Biochemistry Department, Ahmadu Bello University, Zaria, Nigeria
}

\begin{abstract}
In this study, the radical scavenging capacity of Guiera senegalensis, Ipomoea asarifolia and Anisopus mannii were compared. The ascorbic acid equivalent of the stem bark $(2.1 \mathrm{mM})$, leaves $(2.05 \mathrm{mM})$ and root barks $(1.89 \mathrm{mM})$ of Guiera senegalesis are much higher than any part of Ipomoea asarifolia or Anisopus manii. The stem bark, leaves and root bark of Guiera Senegalensis had $\mathrm{IC}_{50}$ of 15.4, 20.0 and $17.0 \mu \mathrm{L}$ respectively, while corresponding parts of Ipomoea asarifolia showed $\mathrm{IC}_{50}$ of 50,42 and $65 \mu \mathrm{L}$, respectively. These results suggest that Guiera senegalensis and Ipomoea asarifolia possess significant antioxidant capacities to warrant further detailed studies on the role of this property in their therapeutic effects.
\end{abstract}

Uniterms: Ipomoea asarifolia/antioxidant potential. Guiera senegalensis/antioxidant potential. Anisopus mannii/antioxidant potential.

Comparou-se a capacidade de sequestrar radicais livres de Guiera senegalensis, Ipomoea asarifolia e Anisopus mannii. O equivalente em ácido ascórbico da casca do caule $(2,1 \mathrm{mM})$, folhas $(2,05 \mathrm{mM})$ e da casca da raiz (1,89 $\mathrm{mM})$ de Guiera senegalesis foi muito mais alto do que qualquer parte da Ipomoea asarifolia e da Anisopus manii. A casca do caule, as folhas e a casca da raiz de Guiera senegalensis apresentaram $\mathrm{IC}_{50}$ de 15,4, 20,0 and 17,0 $\mu \mathrm{Ll}$, respectivamente, enquanto as partes correspondentes de Ipomoea asarifolia apresentaram $\mathrm{IC}_{50}$ de 50,42 e $65 \mu \mathrm{L}$ respectivamente. Esses resultados sugerem que Guiera senegalensis e Ipomoea asarifolia possuem capacidade oxidante significativa que demanda estudos posteriores detalhados acerca do papel dessa propriedade em seus efeitos terapêuticos.

Uniterms: Ipomoea asarifolia/potencial antioxidante. Guiera senegalensis/potencial antioxidante. Anisopus mannii/potencial antioxidante.

\section{INTRODUCTION}

Plants continue to be a major source of medicine, as they have always been throughout human history (Ampofo, 1977; Farnsworth et al., 1985; Eisenberg et al., 1998). A number of these plants from other continents have been reported to exert therapeutic efficacies through their antioxidant activities (Aruoma, 2003; Park, Pezzuto, 2002; Scartezzini, Speroni, 2000; Zhu et al., 2004), but only a few Nigerian and African medicinal plants have been the focus of research (Atawodi, 2005). Ipomoea asarifolia,

\footnotetext{
*Correspondence: S.E Atawodi. Biochemistry Department, Ahmadu Bello
} University, KD80006 - Zaria, Nigeria. E-mail: atawodi_se@yahoo.com
Roemer \& J.A. Schultes, Guiera Senegalensis, J.F. Gmel and Anisopus mannii, N.E. Brown are three Nigerian plants whose potential antioxidant potential have not yet been clearly established.

Ipomoea asarifolia, Roemer \& J.A. Schultes (synonyms: Ipomoea hederifolia) or Morning glory, known in the Hausa language of Nigeria as "Duman Karda" (Kaduna), "Duman ra' afii" (Kano) and "Woba boje" or "Daadi mayo" (Adamawa), is a hairless, succulent perennial weed of the family Convolvulaceae that grows in hydromorphic soils in low lying and inland valleys, streams, and river banks of temperate and tropical countries (Okozie, Agyakwa, 1998). Guiera Senegalensis, J.F. Gmel (Family: Combretaceae), known in Hausa as "Sabera" is a small 
shrub with opposite or sub-opposite leaves that are characterized with scattered black glands, which is widespread in West Africa ((Hutchinson et al., 1954), while Anisopus mannii, N.E. Brown (Synonyms: Anisopus bicoronatus, Anisopus rostriferus) is a glabrous twining shrub, known locally as "Kafi-suga" or "Nanukuna", which is a selfsupporting or climbing epiphyte belonging to the family Asclepiadacecae. This plant may possess succulent or non-succulent anticlockwise twines.

Our survey revealed that Guiera senegalensis, J.F. Gmel, Ipomoea asarifolia and Anisopus mannii, N.E. Brown are used either individually or in combination with other herbs, for the treatment of gastrointestinal disorders and/or diabetes, respectively, in Northern Nigeria. These diseases are known to have biological oxidation as a major etiological factor (Dandona, 1996; Boynes, 1991; Ames et al., 1995; Collier et al., 1990; Cerruti, 1994; Atawodi, 2005). However, there is little or no information in the literature on the mechanism(s) by which Guiera senegalensis, Ipomoea asarifolia and Anisopus mannii exert their therapeutic effects. Therefore, it was considered necessary to evaluate their comparative antioxidant potential to ascertain if this property is one of the underlying bases for their usefulness in folk medicine.

\section{MATERIALS AND METHODS}

\section{Plant collection and identification}

The leaves, stem and root barks of the plants were collected from Sakuru and Dumbi villages of Zaria Local Government Area in Kaduna State, Nigeria. The identities of the three plants were confirmed by the Herbarium of the Department of Biological Sciences, Ahmadu Bello University, Zaria, as Ipomoea asarifolia (Voucher No.6958), Guiera senegelensis (Voucher No.1823) and Anisopus mannii (Voucher No. 217).

\section{Sample preparation and extraction}

Parts of the plants (leaves, stem and roots) were collected, washed rapidly under running water and dried in open air in the laboratory. Dried materials were pounded in a laboratory mortar to a relatively fine texture with a particle size of about $0.2 \mathrm{~mm}$.

One gram $(1.0 \mathrm{~g})$ each of pulverized dry plant parts were weighed into $150 \mathrm{~mL}$ conical flasks and $50 \mathrm{~mL}$ of deionized water was added. The mixtures were then covered with aluminum foil and incubated in a water bath at $37{ }^{\circ} \mathrm{C}$ for two (2) hours, with occasional shaking. Thereafter, $10 \mathrm{~mL}$ of the extracts were centrifuged at 3,000 rpm for
15 minutes. The extraction was repeated in duplicate for all parts of the plants. The supernatants were transferred into clean labeled sample bottles and kept in the refrigerator at $4{ }^{\circ} \mathrm{C}$ until ready for use, usually within the same day.

\section{Assay for antioxidant activity}

The antioxidant assay utilized was based on the scavenging ability of antioxidant(s) in plant extracts towards the stable free radical 1,1-diphenyl-2-picrylhydrazyl (DPPH), which is deep purple in color, to form the corresponding hydrazine with accompanying color change to light purple or golden yellow. This color change is inversely proportional to increasing concentration of the antioxidant in the mixture.

As described by Gyamfi et al. (1999), the reaction tubes contained $1.0 \mathrm{~mL}$ of $0.1 \mathrm{mM}$ DPPH-ethanol solution, $1.0 \mathrm{~mL}$ of ethanol (98\% ethanol), $0.95 \mathrm{~mL}$ of $0.05 \mathrm{M}$ Tris-HCl buffer $\left(\mathrm{P}^{\mathrm{H}} 7.4\right)$, and $50 \mu \mathrm{L}$ of either the extract or standard (Vitamin C) solution wrapped in aluminium foil. The absorbance was measured at $517 \mathrm{~nm}$ exactly 30 seconds after adding each of the extracts, as loss of absorbance at this wavelength is a measure of the radical scavenging capacity of the extracts.

To appreciate the results from the DPPH method, the Ascorbic Acid Equivalent (AAEq) and "Inhibitory Concentration" or $\mathrm{IC}_{50}$ value (the concentration of the substrate that causes $50 \%$ inhibition of the DPPH activity) were established. The $\mathrm{IC}_{50}$ values were estimated by extrapolation from plots of the percent (\%) antioxidant activity against the concentration/volume of the test solutions, while Ascorbic Acid Equivalent was obtained by extrapolation from the standard curve for the ascorbic acid antioxidant activity.

\section{RESULTS}

In this study, the radical scavenging capacity of three plants, namely, Guiera Senegalensis, J.F. Gmel, Ipomoea asarifolia and Anisopus mannii, N.E. Brown, were evaluated and compared using the DPPH radical scavenging method while utilizing ascorbic acid as the standard antioxidant. Thus, during the screening stage, antioxidant activity was expressed as Vitamin C equivalent. Samples with reasonable antioxidant activity were further evaluated for their 50\% inhibitory concentration $\left(\mathrm{IC}_{50}\right)$.

Table I compares the ascorbic acid equivalent of parts of the plant under study. The Ascorbic Acid Equivalent of the stem bark $(2.1 \mathrm{mM})$, leaves $(2.05 \mathrm{mM})$ and root barks (1.89mM) of Guiera senegalesis were much higher than any part of Ipomoea asarifolia or Anisopus 
manii plants. Consequently, the average antioxidant activity expressed as Ascorbic Acid Equivalent was highest in Guiera senegalensis ( $2.05 \mathrm{mM})$, followed by Ipomea asarifolia $(1.7 \mathrm{mM})$ and Anisopus manii $(0.17 \mathrm{mM})$, in this order (Figure 1).

TABLE I - Ascorbic Acid Equivalent of different parts of Guiera senegalensis, Ipomoea asarifolia and Anisopus mannii

\begin{tabular}{lccc}
\hline Plant & Part & $\begin{array}{c}\mathrm{IC}_{50} \text { for } \\
\text { Extracts } \\
(\mu \mathrm{L} / 3 \mathrm{~mL})\end{array}$ & $\begin{array}{c}\text { Radical scavenging } \\
\text { activity -Vitamin C } \\
\text { equivalent }(\mathrm{mM})\end{array}$ \\
\hline Guiera & stem & 15.4 & $2.10 \pm 0.09$ \\
senegalensis & leaves & 20.0 & $2.05 \pm 0.14$ \\
Ipomoea & root & 17.0 & $1.89 \pm 0.08$ \\
asarifolia & leaves & 42.0 & $1.33 \pm 0.06$ \\
& root & 65.0 & $0.52 \pm 0.07$ \\
Anisopus & stem & 50.0 & $0.50 \pm 0.04$ \\
mannii & stem & $\mathrm{ND}$ & $0.20 \pm 0.03$ \\
& root & $\mathrm{ND}$ & $0.19 \pm 0.05$ \\
\hline leaves & $\mathrm{ND}$ & $0.15 \pm 0.06$ \\
\hline
\end{tabular}

Vitamin C Equivalent was calculated based on the triplicate analysis of two extracts per sample; $\mathrm{ND}=$ Not determined

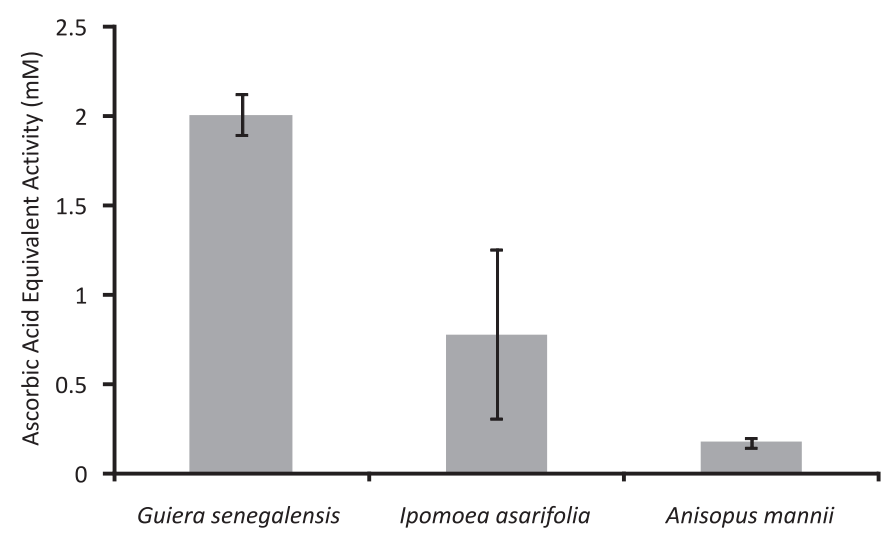

FIGURE 1 - Comparison of average antioxidant activity of all parts of Guirea senegalensis, Ipomea asarifolia and Anisopus manii

The $\mathrm{IC}_{50}$ of those plant parts that were amenable to the procedure adopted are presented in Table I. It should be noted that the lower the $\mathrm{IC}_{50}$ value, the stronger the antioxidant potential. Using extracts of $1 \mathrm{~g}$ samples boiled in $150 \mathrm{~mL}$ water, the stem bark, leaves and root barks of Guiera senegalensis had $\mathrm{IC}_{50}$ of $15.4,20.0$ and $17.0 \mu \mathrm{L}$ respectively, while corresponding parts of Ipomoea asarifolia showed $\mathrm{IC}_{50}$ of 50, 42 and $65 \mu \mathrm{L}$, respectively (Table I). Thus, all parts of Guiera senegalensis possessed greater antioxidant potential than those of Ipomoea asarifolia and obviously, also more potential than Anisopus mannii, whose antioxidant activity was too low to be amenable to the $\mathrm{IC}_{50}$ assessment procedure adopted.

\section{DISCUSSION}

This investigation compared the in vitro antioxidant potential of different parts of three medicinal plants which are used locally for treatment of several ailments in the northern part of Nigeria. Of these plants, Guiera senegalensis showed the highest antioxidant activity followed by Ipomoea asarifolia and Anisopus mannii in this order, as evidenced from their Ascorbic Acid Equivalent values (Table I and Figure 1) as well as their $\mathrm{IC}_{50}$ values (Table I)

Today, medicinal plants are showing tremendous promise for preventive intervention in the pathogenesis of many diseases, as well as in their treatment (Atawodi, 2005), especially the ROS-mediated diseases such as cancer (Mantle et al., 2000; Tsao et al., 2004; Surh, Ferguson, 2003; Mehta, Pezzuto, 2002; Park, Pezzuto, 2002; Bravo, 1998), ulcer (Reppeto, Llesuy, 2002; Borelli, Izzo, 2000), diabetes (Sabu, Kuttan, 2002) and others (Youdim, Joseph, 2001; Perry et al., 1998; Lampe, 2003; Miller, 1998). The relationship between the antioxidant compounds in plants and their effectiveness in the treatment of these diseases have been previously described (Reppeto, Llesuy, 2002; Sabu, Kuttan, 2002; Yang et al., 2001; Bravo, 1998; Manach et al., 2004).

Guiera senegalensis is reportedly useful in the treatment of malaria (Ancolio et al.,2002), fungal diseases (Silva, Gomes, 2003) and snake bite (Abubakar et al., 2000), while in Northern Nigeria, the plant is also reported to be useful in the treatment of gastrointestinal disorders and skin diseases. Although oxidative stress may have little or no role to play in the etiology of these diseases, except in gastrointestinal disorders such as ulcer, the strong antioxidant potential of this plant suggests that it is plausible it may exert therapeutic efficacy in oxidativestress related diseases for which it is not currently recognized. This strong antioxidant activity is consistent with its phytochemical constituents which include alkaloids (Ancolio et al., 2002), guirenone and other polyphenols (Silva, Gomes, 2003; Le Grand, 1989). In fact, Bucar et al. (1989) isolated 5-methylflavesperone and rhamnetin from Guiera senegalensis and demonstrated that while rhamnetin strongly inhibited peroxidation of phospholipids liposomes, the former possessed little or no such activity. Similarly, using a combination of techniques such as TLC, HPLC, UV spectroscopy and NMR, the presence of catechin, myrecitrin, rutin and quercetin in Guiera senegalensis have been described by other researchers (Ficarra et al., 1997). That these phytochemicals are potent antioxidant compounds has been well demonstrated (Bravo, 1998; Manach et al., 2004). 
The moderate antioxidant potential observed for Ipomoea asarifolia is consistent with its reported content of the antioxidant compounds, triacylated and tetraglucosylated anthocyanins (Pale et al., 2003) and its use as an anti-diabetic in Northern Nigerian traditional medicine. These assertions are further supported by information in the literature which suggest that other members of the Convolvulaceae family, which also contain the phytochemical, anthocyanin (Philpott et al., 2004) are effective agents in the management of biological radical-induced diseases and pathological processes such as diabetes (Kusano et al., 2001; Ludvik et al., 2004), mutagenesis (Yoshimoto et al., 1999) and memory loss as well as other age-related degenerative syndromes (Cho et al., 2003).

Anisopus mannii is an anti-diabetic herb in Northern Nigeria, but a search of the literature appears to suggest no record of its phytochemistry or medicinal importance in any other part of the world. However, this investigation indicated that all parts of the plant have poor antioxidant activity. Therefore, its medicinal efficacy, if any, must be mediated by other mechanisms other than scavenging of biological free radicals.

Based on the results obtained in the present study, it may be concluded that Guiera senegalensis and Ipomoea asarifolia possess sufficient antioxidant activity to warrant further detailed study of their pharmacology and phytochemistry.

\section{ACKNOWLEDGEMENTS}

We would like to thank the Alexander von Humboldt Foundation $(\mathrm{AvH})$ of Bonn Germany for the donation of materials in support of the research of SEA. We are grateful to Drs B. Spiegelhader and H. Gehauser of the German Cancer Research Centre (DKFZ), Heidelberg, Germany for donation of DPPH.

\section{REFERENCES}

ABUBAKAR, M. S.; SULE, M. I.; PATEH, U. U.; ABDURAHMAN, E. M.; HARUNA, A. K.; JAHUN, B. $\mathrm{M}$. In vitro snake venom detoxifying action of the leaf extract of Guiera senegalensis. J. Ethnopharmacol., v.69, p.253-257, 2000.

ANCOLIO, C.; AZAS, N.; MAHIOU, V.; OLLIVIER, E.; DI GIORGIO, C.; KEITA, A.; TIMON-DAVID, P.; BALANSARD, G. Antimalarial activity of extracts and alkaloids isolated from six plants used in traditional medicine in Mali and Sao Tome. Phytotherapy Res., v.16, p.646-649, 2002.
AMES, B. N.; GOLD, L. S.; WILLET, W. C. The causes and prevention of cancer. Proc. Natl. Acad. Sci., v.92, n.12, p.5258-5265, 1995.

AMPOFO, O. Plants that heal. World Health Report., v.26, p.28-30, 1977.

ATAWODI, S. E. Antioxidant potentials of African medicinal plants. African J. Biotechnol., v.4, p.128-133, 2005.

ARUOMA, O. I. Methodological considerations for characterizing potential antioxidant actions of bioactive components in food plants. Mut. Res., v.523-524, p.9-20, 2003.

BORELLI, F.; IZZO, A. A. The plant kingdom as a source of anti-ulcer remedies. Phytother. Res., v.14, p.581-591, 2000.

BAYNES, J. W. Role of oxidative stress in the development of complications in diabetes. Diabetes, v.40, p.405-411, 1991.

BRAVO, L. Polyphenols: Chemistry, dietary sources, metabolism and nutritional significance. Nutr. Rev., v.11, p.317-333, 1998.

BUCAR, F.; RESCH, M.; BAUER, R.; BURITS, M.; KNAUDER, E.; SCHUBERT-ZSILAVECZ, M. 5-Methylflavasperone and rhamnetin from Guiera senegalensis and their antioxidative and 5-lipoxygenase inhibitory activity. Pharmazie, v.53, p.875-878, 1998.

CERUTTI, P. A. Oxy-radicals and cancer. Lancet, v.344, p.862863, 1994.

CHO, J.; KANG, J. S.; LONG. P. H.; JING, J.; BACK, Y.; CHUNG, K. S. Antioxidant and memory enhancing effects of purple sweet potato anthocyanin and cordyceps mushroom extract. Arch. Pharm. Res., v.26, p.821-825, 2003.

COLLIER, A.; WILSON, R.; BRADLEY, H.; THOMSON, J. A.; SMALL, M. Free radical activity in type 2 diabetes. Diabetes, v.7, p.27-30, 1990.

DANDONA, P.; THUSU, K.; COOK, S.; SNYDER, B.; MAKONOSKI, J.; AMRSTRONG, D.; NICOTORA, T. Oxidation damage to DNA in Diabetes Mellitus. Lancet, v.347, p.444-445, 1996. 
EISENBERG, D. M.; DAVIS, R. B.; ETTNER, S. L.; APPEL, S.; WILKEY, S.; VON ROMPAY, M.; KESSLER, R. C. Trends in alternative medicine use in the United States, 1990-1997. J. Amer. Med. Assoc., v.280, p.1569-1575, 1998.

FARNSWORTH, N. K.; AKERELE, O.; BINGUL, A. S.; SOEJARTO, D. D.; GNO, Z. Medicinal plants in therapy. Bull. World Health Org., v.63, p.965-981, 1985.

FICARRA, R.; FICARRA, P.; TOMMASINI, S.; CARULLI, M.; MELARDI, S.; DI BELLA, M. R.; CALABRO, M. L.; DE PASQUALE, R.; GERMANO, M. P.; SANOGO, R.; CASUSCELLI F. Isolation and characterization of Guiera senegalensis J. F.Gmel. active principles. Boll. Chim. Farm., v.136, p.454-459, 1997.

GYAMFI. M. A.; YONAMINE, M.; ANIYA Y. Free radical scavenging activity of medicinal herb of Ghana: Thoninngea sanguine on experimentally induced liver injuries. Gen. Pharmacol., v.32, p.661-667, 1999.

HOWES, M. J.; HOUGHTON, P. J. Plants used in chinese and indian traditional medicine for improvement of memory and cognitive function. Pharmacol. Biochem. Behav., v.75, p.513-27, 2003.

HUTCHINSON, J.; DALZIEL J. M.; KEAY R. W. J. Flora of west tropical Africa. 2.ed. London: Crown Agents Publishers, 1954. v.1, part.1, p.275.

KUCHT, S.; GROSS, J.; HUSSEIN, Y.; GROTHE, T.; KELLER, U.; BASAR, S.; KONIG, W. A.; STEINER, U.; LEISTNER, E. Elimination of ergoline alkaloids following treatment of Ipomoea asarifolia (Convolvulaceae) with fungicides. Planta, v.219, p.619-225.

KUSANO, S.; ABE, H.; TAMURA, H. Isolation of antidiabetic components from white-skinned sweet potato (Ipomoea batatas L.). Biosci. Biotechnol. Biochem., v.65, p.109-114, 2003.

LAMPE, J. W. Spicing up a vegetarian diet: chemopreventive effects of phytochemicals. Am. J. Clin. Nutr., v.78, suppl.3, p.579S-583S, 2003.

LE GRAND, A. Anti-infective phytotherapies of the treesavannah, Senegal (occidental Africa). III: A review of phytochemical substances and the antimicrobial activity of 43 species. J Ethnopharmacol. v.25, p.315-338, 1989.
LUDVIK, B.; NEUFFER, B.; PACINI, G. Efficacy of Ipomoea batatas (Caiapo) on diabetes control in type 2 diabetic subjects treated with diet. Diabetes Care, v.27, p.436-440, 2004.

MANACH, C.; SCALBERT, A.; MORAND, C.; REMESY, C.; JIMENEZA. Polyphenols: Food sources and bioavailability. Am. J. Clin. Nutr., v.79, p.727-747, 2004.

MANTLE, D.; LENNARD, T. W.; PICKERING, A. T. Therapeutic applications of medicinal plants in the treatment of breast cancer: a review of their pharmacology, efficacy and tolerability. Adverse Drug React. Toxicol. Rev., v.19, p.223-240, 2000.

MEHTA, R.G.; PEZZUTO, J. M. Discovery of cancer preventive agents from natural products: from plants to prevention. Curr. Oncol. Rep., v.4, p.478-486, 2002.

MILLER, A. L. Botanical influences on cardiovascular disease. Altern. Med. Rev., v.3, p.422-431, 1998.

OKEZIE, A.; AGYAKWA, C. W. A handbook of West African weeds. 2.ed. Ibadan, Nigeria: International Institute of Tropical Agriculture, 1998. 228 p.

PALE, E.; KOUDA-BONAFOS, M.; NACRO, M.; VANHAELEN, M.; VANHAELEN-FASTRE, R. Two triacylated and tetraglucosylated anthocyanins from Ipomoea asarifolia flowers. Phytochem., v.64, p.13951399, 2003.

PARK, E. J.; PEZZUTO, J. M. Botanicals in cancer chemoprevention. Cancer Metastasis Rev., v.31, p.231$255,2002$.

PERRY, E. K.; PICKERING, A. T.; WANG, W. W.; HOUGHTON, P.; PERRY, N. S. Medicinal plants and Alzheimer's disease: Integrating ethnobotanical and contemporary scientific evidence. J. Altern. Complement. Med., v.4, p.419-428, 1998.

PHILPOTT, M.; GOULD, K. S.; LIM, C.; FERGUSON, L. R. In situ and in vitro antioxidant activity of sweetpotato anthocyanins. J. Agric. Food Chem., v.52, p.1511-1513, 2004.

REPETTO, M. G.; LLESUY, S. F. Antioxidant properties of natural compounds used in popular medicine for gastric ulcers. Braz. J. Med. Biol. Res., v.35, p.523-534, 2002. 
SABU, M. C.; KUTTAN, R. Antidiabetic activity of medicinal plants and its relationship with their antioxidant property. J. Ethnopharmacol., v.81, p.155-160, 2002.

SCARTEZZINI, P.; SPERONI, E. Review on some plants of indian traditional medicine with antioxidant activity. $J$. Ethnopharmacol., v.71, p.23-43, 2000.

SILVA, O.; GOMES, E. T. Guieranone A, a naphthyl butenone from the leaves of Guiera senegalensis with antifungal activity. J. Nat. Prod., v.66, p.447-449, 2003.

SURH, Y. Z.; FERGUSON, L. R. Dietary and medicinal antimutagens and anticarcinogens: molecular mechanisms and chemopreventive potential-highlight of a symposium. Mut. Res. v.428, p.305-327, 2003.

TSAO, A. S.; KIM, E. S.; HONG, W. K. Chemoprevention of cancer. CA Cancer J. Clin., v.54, p.150-180, 2004.
YANG, C. S.; LANDU, J. M.; HUANG, M. T.; NEWMARK, H. L. Inhibition of carcinogenesis by dietary polyphenolic compounds. Ann. Rev. Nutr., v.21, p.381-406, 2001.

YOSHIMOTO, M.; OKUNO, S.; YOSHINAGA, M.; YAMAKAWA, O.; YAMAGUCHI, M.; YAMADA, J. Antimutagenicity of sweet potato (Ipomoea batatas) roots. Biosci. Biotechnol. Biochem., v.63, p.537-541, 1999.

YOUDIM, K. A.; JOSEPH, J. A. A possible emerging role of phytochemicals in improving age-related dysfunction: a multiplicity of effects. Free Radic. Biol. Med. v.30, p.583594.

ZHU, Y.Z.; HUANG, S. H.; TAN. B. K.; SUN, J.; WHITEMAN, M.; ZHU, Y. C. Antioxidants in Chinese herbal medicines: a biochemical perspective. Nat. Prod. Rep., v.21, p.478$489,2004$.

Received for publication on $03^{\text {rd }}$ April 2009 Accepted for publication on $02^{\text {nd }}$ December 2009 